\title{
Introduction: Global Shakespeare for Anglophone Audiences
}

Reflecting on the 2012 Globe to Globe Festival, Bridget Escolme hopes that this unique project might 'paradoxically be the beginning of a decentring of Shakespeare in global knowledge production.' 'What questions,' she asks, 'might this Festival continue to provoke that aren't about Shakespeare? And how might theatres and universities start to explore and answer them' (309)? Escolme joins other scholars left asking questions, about Shakespeare, 'non-Shakespeare' and performance, in reaction to an unprecedented few years of foreign productions staged for Anglophone audiences. Many of those excellent responses are collated in Shakespeare Beyond English (2013), edited by Susan Bennett and Christie Carson, and A Year of Shakespeare (2013), edited by Paul Edmondson, Paul Prescott and Erin Sullivan. This special edition of Multicultural Shakespeare is part of that response and seeks to engage with and develop the debate started by these two important books. We do this not least with a review of both books which productively places them in dialogue with one another, but also with a rich, eclectic set of articles that considers the genesis of the Globe to Globe Festival, foreign Shakespeare performance practices, the politics of translation and the ethics of reviewing such productions, amongst other things.

A Year of Shakespeare offers an 'archive of accounts of an exceptionally wide range of theatrical experiences made available within a short space of time and originating in many different cultures' (Wells xxiii). Similarly, Shakespeare Beyond English serves, according to its editors, 'as a scholarly archive of the Globe to Globe Festival'; albeit one they hope 'challenge[s] the business of Shakespeare' and so 'is a great deal more' (Bennett and Carson 3). Rather than emulate these comprehensive works, this journal is not an archive but rather a diverse snapshot of scholars' analysis of foreign Shakespeare in 2014, focussing on a range of performances from Globe to Globe, to the Edinburgh International Festival, to the Royal Shakespeare Complete Works Festival. Escolme wonders

\footnotetext{
* Lecturer in Early Modern English, University of Kent.

** London Shakespeare Centre, King's College London.
} 
how theatres and universities might begin to explore the questions raised by foreign Shakespeare and we hope that this journal begins some of that exploratory work. Shakespeare remains a focus but, again picking up on Escolme's thoughts about questions that are not about the early modern playwright, articles here offer thoughts on contemporary Chinese, Indian and Polish theatre practices from practitioners and researchers working in these areas. The next few pages introduce the articles that follow, but also seek to identify three of the reoccurring themes that they examine: performance spaces, languages and reception.

\section{Performance Spaces}

For David Wiles, 'the play-as-event belongs to the space, and makes the space perform as much as it makes actors perform' (1); the importance of space, as asserted by Wiles, is confirmed by the discussion of many foreign Shakespeare productions. The way a space 'performs' - in the sense of working both with or even against a production - is pertinent for shows which are transferred across not only different theatre spaces but different countries too. For the Globe to Globe Festival, the specific performance conditions of London's reconstructed theatre challenged many companies performing during 2012.

Reviewing Andrea Baracco and Vincenzo Manna's Giulio Cesare (Julius Caesar) for Shakespeare Beyond English, Sonia Massai points out that 'the performance space offered by the Globe is not neutral' and often 'clashes with the aesthetic and more generally artistic principles that inform the theatrical language and approach' shared by some directors, including Baracco (97). For Massai, Baracco's production evoked a sense of 'dislocation' because 'a theatrical language which had originated in a very different type of theatre, where light and sound thoroughly inform the artistic vision of those who work within it, clashed with the performance space offered by the Globe stage' (97). In the same book, Julie Sanders discusses the opposite of this effect in her review of the Renegade Theatre Company of Lagos' re-working of The Winter's Tale, where the spatial practices of the Globe and the theatrical language of the production were attuned. Sanders notes that '[i]t has become something of a given in writing about the Globe to pay tribute to its capacity for involving spectators in the production of the "event"' but, she points out, 'audience participation is also central to Apidán theatre practice' (247). In this production 'it was through the medium of audience participation that the active claiming of space could be most clearly registered' (247). In Julius Caesar and The Winter's Tale, according to their reviewers, we get a sense of the spectrum of performance potential of foreign Shakespeare at the Globe: 'dislocation' from the space to a 'claiming' of the theatre. 
Like Massai and Sanders, several articles in this collection attempt to think through the implications of the Globe as a performance space for global Shakespeare, and the ways in which companies in 2012 made use of the space. In Amy Kenny's article we get a sense of this process from an inside perspective: Kenny worked in the Globe's Higher Education and Research Department, interviewing companies during their time at the theatre. In analysing the 'role of language' and the process of translating Shakespeare's plays, she thinks through the implications of translation choices on staging and audience reception in the space of the Globe. Kevin Quarmby's article also offers a unique perspective of the Festival based on the recorded interviews of US documentary-maker Steve Rowland, who was given access to Globe theatre staff and Globe to Globe performers to create a rich patchwork of oral histories describing the event. Quarmby's analysis of these oral histories reveals the decisions and events involved in the initial idea for the Festival, bringing the different companies and funders together and the choices of countries and plays. In this fascinating account of how and why the 2012 season came about, Quarmby considers the role that the 'materiality of the Globe's theatrical space' played in an especially crucial moment in the development of the Festival.

In Aneta Mancewicz's article we encounter the RSC Swan Theatre, Stratford-Upon-Avon, another iconic building for the performance of Shakespeare. Mancewicz examines the RSC and The Wooster Group's co-production of Troilus and Cressida, which, she suggests, was 'probably the most challenging and the most challenged performance at the World Shakespeare Festival.' In her account we see the clash of two very different theatrical cultures and languages that undoubtedly influenced the somewhat negative critical response to the work. Similarly in conversation with Grzegorz Bral, Aleksandra Sakowska encourages the Polish director of Song of the Goat to think through the performance and cultural implications of adapting Macbeth for the RSC Complete Works Festival in 2010. Like Mancewicz, Sakowska is interested in the ways in which the critical response to foreign Shakespeare, in this case Bral's Macbeth, and the 'languages of the avant-garde.'

Thus, in part, this special journal edition considers the interaction between space and performance in the case of foreign Shakespeare. The following articles offer insights into the means by which sites such as the Globe and the RSC that have their own unique cultural meanings, and spatial languages, contend, attune to or indeed work against productions that bring their own meanings and languages. 


\section{Languages}

From spatial language, we move now to consider specifically the language of translation. When it comes to Shakespearean performances there is certainly value attached to the English text and language, but 'Foreign Shakespeare' has other assets, bringing Shakespeare's plays to life in a different theatrical traditions. Dennis Kennedy's seminal book Foreign Shakespeare with its provocative essay 'Shakespeare without His Language' sealed, it seems, the fate of non-English performances. Engagement with translations of Shakespeare into foreign languages and their presence in performance, through surtitles, has been minimal over the history of performance for Anglophone audiences. Indeed, some Shakespearean scholars have warned about the implications that stem from the idea of 'Shakespeare without his language.' In an article which advocates more research engagement with Shakespeare in languages other than English, Ton Hoenselaars asks 'if we are really prepared to see Shakespeare as a world author, rather than as an English writer, can we afford to ignore the linguistic perspective on that world?' (275)

At the Globe to Globe Festival, Anglophone audiences were denied the opportunity to engage with translations of Shakespeare. The Festival used sidescreens with short summaries of key scenes and plot developments that were timed to flash up at the correct points in performance - although in some cases summaries were misleading or incorrectly timed. Margherita Laera has considered the Globe's surtitles at length, in a blog that resonates with Hoenselaars question. Laera wonders 'what might have happened, had we been offered Shakespeare plays in back-translation on the side-screens of Globe to Globe productions.' She points out that a 'world of wonderful paradoxes and contradictions might have emerged, one that might have unsettled Shakespeare connoisseurs and English-speaking spectators alike'; and suggests she would have taken 'great pleasure' in experiencing 'contradictions, the inevitable mismatches created by translation and the opportunities for new meaning offered by de- and re-contextualisation'. Laera proposes what such translations might have been: Imagine, for instance, a subtitle going: "Being or not being, that is here the problem”; or "Oh Romeo, Romeo, why are you Romeo?” As Laera's proposals demonstrate, re-translation of 'foreign Shakespeare' might certainly have challenge and expanded Anglophone audiences' ideas of Shakespeare, not without language, but in other languages.

In her article for this journal, Kenny also explores translation at the Globe to Globe Festival, the implications of surtitles and performers' engagement with Shakespeare in English and their own language. Her interviews with cast members suggest rich linguistic exchanges took place (exchanges that, Laera and Hoenselaars might note were not shared with the audience because of the minimal use of translation). For example, Kenny describes Ngakau Toa's 
Troilus and Cressida which drew on archaic Maori to translate the classical allusions of Shakespeare's text. In the case of other productions, such as Richard II in Palestinian Arabic, translations in contemporary vernacular were used. The article gives us an insight into the reflections on Shakespeare's language but also a range of other languages brought about by the Globe to Globe Festival.

A particular type of 'language' considered by Kenny and others in this journal is that of performance. In particular, the physical language of gesture, movement and posture that emerges to facilitate communication between Anglophone audiences and foreign performers. Describing Song of Goat's Macbeth production, Sakowska notes that it is the 'performers' bodies and voices speak volumes' and that as an audience member 'you need to participate with all your senses.' The two reviews which end this journal are similarly attuned to the nuanced performative work of actors, directors and other theatre practitioners staging foreign Shakespeare for Anglophone audiences, and what the work of these theatre-makers reveals about not only their interpretation of the plays but the political and cultural ideas they wish to convey. Saffron Walkling's review of Lin Zhaohua's Coriolanus (staged at Edinburgh International Festival in 2012) analyses its 'modernist,' 'bare' and 'abstract' stage aesthetic. Having interviewed the director in 2011, Walkling is able to offer a well informed and contextualised discussion of Zhaohua's Coriolanus, which unpicks the interplay between politics, translation and performance in his work. Reviewing Haissam Hussain's The Taming of the Shrew, performed at Globe to Globe in 2012, Thea Buckley examines the importance of costume in this production. For Buckley, 'metamorphic' costume changes in Hussain's Shrew embodied the play's gender politics but, also, those of contemporary Pakistan, a country, she notes, consistently listed in the bottom three most dangerous countries worldwide for women on the World Economic Forum's Gender Gap Report. In their attention to the performance, politics and culture in foreign Shakespeare productions, several contributors to this edition demonstrate that the text, in English or not, is just one of the many 'languages' spoken by actors and understood by audiences.

\section{Reception}

A reoccurring point that emerges in several articles is the critical response to foreign Shakespeare. Reviews of such productions often, contributors point out, reveal more about the values of those reviewers than the productions themselves. As Walkling wonders in her discussion of reviews of Lin's Coriolanus, is there an 'inability of the audience [and reviewers] to read cultural signifiers?' As such, reviewers fell back on their own racial and cultural signifiers as to what a 'right' Asian Shakespearean performance should be. As Walkling notes, reviewers 'inability to read the politics in contemporary Chinese performance led to their 
sense that the production was therefore inauthentic, both culturally and politically'; a point Walkling is able to dismiss through a nuanced understanding of contemporary Chinese theatre and politics. Similarly, Mancewicz suggest that the criticism of the Wooster Group and RSC Troilus and Cressida not only revealed an inability to read other kinds of theatre work but 'brought out the conditions determining the success of Shakespearean staging for more traditional British spectators and critics.' The reception of foreign Shakespeare in Anglophone countries, therefore, reveals the structures and criteria through which Shakespearean theatre is assessed.

Mancewicz's close reading of the critical response to Troilus and Cressida suggests that 'mainstream critics and audiences tend to perceive Shakespeare's plays primarily as literary texts that are to be interpreted with respect for their intellectual and poetic complexity.' For some reviewers and audiences, then, the text, the language is paramount. Yet, for the Wooster Group and for other performers, the texts are 'dramatic scripts that might be adapted and altered at liberty for the purpose of a stage performance' (Mancewicz). It is something other than text that motivates and inspires their interpretation. In interview with Sakowska, Song of the Goat director Bral expresses this attitude clearly:

\footnotetext{
I'm not interested in the meaning of the text or what it sounds like. I'm interested in the musicality of the text [...] When I read Shakespeare, the words are on the surface somewhere, and beneath that there is a melting pot of emotions. What I experience is not the textual layer but that emotional melting pot.
}

In order to analyse this approach to Shakespeare explored by foreign performers working in translation, critics must re-assess their own values, languages and agendas. Several articles in this journal aim to do so and problematise existing responses to foreign Shakespeare.

Alongside reviewers, we should not forget the reception of these productions in the moment of performance. Audience response to recent performances is a reoccurring theme in many of our articles. In her Foreword to this collection, Ann Thompson identifies the significance of foreign London communities who came to see their 'home' productions at Globe to Globe. The 'publicity for the festival had clearly reached the appropriate London communities,' she points out, 'and they turned out in force and reacted enthusiastically [...] there was a palpable sense of warmth and pride in the house: "This is our language; these are our actors; this is our Shakespeare.”' Indeed, as Kenny discusses, during the Festival in many respects 'a patchwork of the cultures and peoples that London encompassed were embodied on the Globe stage,' as each community came to claim the space of the theatre. In her review of The Taming of the Shrew, Buckley looks particularly at the way in which the Pakistani 
community responded to the play, whilst wisely cautioning and exploring the fact that 'the rarity of "Pakistani Shakespeare" makes it [...] difficult to typify an audience at all for the phenomenon.'

There have been some nuanced, thoughtful and sensitive response to the recent spate of foreign Shakespeare performed for Anglophone audiences. In his discussion of Shakespeare Beyond English and A Year of Shakespeare, Derek Dunne points out that the 'strongest' performers reviews occurred when writers had 'a firm grasp of the production's local contexts as well as its global import'; thereby actively overcoming the 'position of ignorance' that they (unusually) found themselves in whilst reviewing these productions. The publication of both books demonstrates that the Globe to Globe Festival and the Cultural Olympiad have had a tangible impact on Shakespearean scholarship: Dunne's review pulls out the interesting crossover between both books, as well as the key issues they raise for those interested in Shakespearean performance. Indeed several other contributors refer to both works, demonstrating that there places as important touchstones for thinking through the performance of foreign Shakespeare. We hope that this snapshot collection, as we have termed it, can also provide similar points of reference and intrigue for future discussion.

\section{Conclusion}

This introduction has offered a roadmap through the following articles, via three reoccurring themes (Performance Space, Language and Reception). However, our approach is by no means exhaustive or exclusive: the edition raises a range of other issues and questions we hope will inspire future work in this area. For example, how do we usefully archive such productions? How do we better prepare and inform reviewers? What production processes are involved in such performances? Has the recent trend in foreign Shakespeare had a lasting impact, and what is the nature of that impact? Perhaps most importantly, then, we hope that this special edition journal begins to answer but also simply points out some of the intriguing unanswered questions that foreign Shakespeare performed for Anglophone audiences raises for academics, theatre reviewers and practitioners alike.

\section{WORKS CITED}

Bennett, Susan, and Christie Carson, Eds. Shakespeare Beyond English: A Global Experiment. Cambridge: Cambridge University Press, 2013.

Escolme, Bridget. "Decentring Shakespeare: A Hope for Future Connections.” Shakespeare Beyond English. Ed. S. Bennett and C. Carson. Cambridge: Cambridge University Press, 2013. 308-312. 
Hoenselaars, A.J. "Translation Futures: Shakespearians and the Foreign Text." Shakespeare Survey 62 (2009): 273-282.

Laera, Margherita. "In Praise of Translation: On Watching Shakespeare in a Foreign Language.” Web. Jan 2014. http://bloggingshakespeare.com/year-of-shakespearein-praise-of-translation.

Massai, Sonia. “Art of Darkness: Staging Giulio Cesare at the Globe Theatre.” Ed. S. Bennett and C. Carson. Cambridge: Cambridge University Press, 2013. 92-100.

Sanders, Julie. "Creative Exploitation and Talking Back: Renegade Theatre's The Winter's Tale or İtàn Ògìnìntìn ('Winter's Tales').” Ed. S. Bennett and C. Carson. Cambridge: Cambridge University Press, 2013. 241-250.

Wells, Stanley. "Foreword.” A Year of Shakespeare. Ed. P. Edmondson, P. Prescott and E. Sullivan. London: Bloomsbury Arden Shakespeare, 2013. xxiii-xxv.

Wiles, David. A Short History of Western Performance Space. Cambridge: Cambridge University Press, 2003. 